\title{
OFFENSES RELATED OF GOODS / ITEMS ACROSS THE CUSTOMS BORDER: NATURE AND BUSSINES COMPONENT
}

\author{
Palamarchuk G. V., Neledva N. V.
}

\section{INTRODUCTION}

In today's context, shadow economic activity plays a significant role in creating a unique socio-economic and cultural space, adversely affecting the development of the national economy as a whole and its strategic industries, in particular, contributing to the development of other illegal activities. Among the shadow business areas, special attention should be paid to its types that go beyond national borders. These are offenses related to the movement of goods / items across the customs border.

Today, not only smuggling but also other offenses related to the movement of goods / items across the customs border are a threat to Ukraine, as noncriminalized forms of cross-border shadow business cause the greatest economic and political damage. But their criminological analysis is complicated by the inconsistency of the legal assessment of a number of such offenses, the presence of temporarily occupied territories with different legal status, etc.

Given the predominantly organized nature of offenses related to the movement of goods / items across borders, the distribution of roles within criminal groups, the ramifications and resilience of corrupt relationships of the perpetrators, the organizational and legal imperfection of the available preventive measures, thorough criminological intelligence on the current state of these offenses in Ukraine at the present stage and improving its prevention system.

Comprehensive analysis of offenses related to the movement of goods / items across the customs border as a separate criminological group of socially dangerous economic activities provides an opportunity for a clearer definition of the main directions of their prevention.

\section{Offenses relating to the movement of goods / items across the customs border: nature and legal nature}

In terms of the historical patterns of the notion of offenses related to the movement of goods / items across the customs border, historically, everything started from smuggling - the economic and legal nucleus of the whole set of offenses. In the context of intelligence on the essence of this action, it is advisable to refer to foreign sources. 
A classic study of the nature of smuggling and its impact on the well-being of society is the work of J. Bhagwati and B. Hansen (1973) ${ }^{1}$. They were the first to introduce the theory of smuggling, which was considered solely as an import-substituting economic activity, and showed that smuggling was able to improve public well-being because it could transfer resources from the public to the private sector. As for the potential economic costs of the smuggler, transportation costs were indicated. The latter position was supplemented by Sheikh M.A. (1974) - an indication of risk costs (relative to goods confiscated and taxed $)^{2}$.

Model M. Pitt (1981) explained the smuggling of goods using the export duty: the reason for smuggling was suggested to be the excess of the domestic price over the world except for the duty, that is, under these conditions, legal exports brought absolute losses. However, firms are forced to export legally solely to cover smuggling activities in order to reduce the cost of smuggling ${ }^{3}$.

In his study, On Northeastern Theory of Smuggling (1988), D. Norton views smuggling as a crime of opportunity made possible by different tariffs or price disparities in different markets ${ }^{4}$.

F. Chowdhury (1999) proposed a model of production-based smuggling, in which price disparities are critical as an incentive to engage in smuggling 5 . These disparities are caused by the presence of internal indirect taxes and import duties. Therefore, the reduction of internal taxes is considered in the context of the ability of an internal producer to offer goods at lower prices and to reduce price disparities that stimulate smuggling. However, the author suggested that there was a limit beyond which a reduction in domestic production taxes would not be able to add competitive advantages. Thus, confiscation measures are needed to increase the cost of smuggling and make it uncompetitive.

The Encyclopedia of Criminology and Deviant Behavior defines smuggling as the illegal import of goods from one jurisdiction to another. Illegal operations may include the importation or exportation of illicit goods (eg drugs) or the evasion of foreign trade taxes, including duties, on goods,

${ }^{1}$ Bhagwati J., Hansen B. A Theoretical Analysis of Smuggling. The Quarterly Journal of Economics. Vol.87. № 2. (May, 1973). P. 172-187.

${ }^{2}$ Sheikh M.A. Smuggling, production and welfare. Journal of International Economics. 1974. № 4. P. 355-364.

${ }^{3}$ Pitt M. Smuggling and price disparity. Journal of International Economics. 1981. № 11. P. 447-458.

${ }^{4}$ Norton D.A. On the Economic Theory of Smuggling. Economica, New Series. Vol. 55. № 217. (Feb., 1988). P. 107-118.

${ }^{5}$ Chowdhury F.L. Smuggling, Tax Structure and The Need for Anti-Smuggling Drive. Fiscal Frontier. Vol.VI. 2000. URL: http://www.answers.com/topic/faizul-latif-chowdhury. (дата звернення: 10.12.2019) 
exports or imports of which are subject to customs duties (eg diamonds, cigarettes). Price disparities and different levels of duty rates in different jurisdictions or at different times determine the likelihood of smuggling ${ }^{6}$.

Thus, economists emphasize that smuggling is motivated by risk-taking strategies driven by the desire to avoid taxes or to obtain money from the sale of illegally imported goods. Complementing the view that economic conditions affect smuggling, economists also argue that smuggling affects price disparities and other economic aspects.

It should be emphasized that in most Western criminological studies, smuggling is defined as a "crime of opportunity" and its commission is intended to make a profit. Based on this concept of smuggling, Paulus and Gimron's (1981) studies have shown that individuals crossing the border are clearly aware of the illegality of smuggling ${ }^{7}$. When crossing the border, the smuggler must directly decide on the non-declaration of goods and, accordingly, on the violation of the law. As D. Braithwaite pointed out, if economic agents do not act in accordance with the laws, then they certainly act in the light of the existence of laws ${ }^{8}$. Accordingly, persons who commit various offenses when crossing the border try to rationally weigh the pros and cons of violations of customs rules and choose the type of behavior that benefits them in the current situation.

Smuggling is distinguished from "gray imports", although tax evasion is manifested in the case of both "gray imports" and smuggling ("black imports"). The term "gray imports" refers to goods being transported to a country with a decrease in tariff payments due to false declaration, that is, "gray schemes" of import should mean a decrease in the customs value of goods, wrong definition of the country of origin of goods and their codes 9 . Smuggling is a situation where moving across the customs border of a particular product / item does not exclude taxes at all, the fact of crossing the border is not recorded in any customs documents.

This action is aimed at avoiding / neutralizing:

1. Control in the event that the moving goods / items do not meet the existing safety requirements or are prohibited from import / export.

${ }^{6}$ Black Market Contraband Index. URL: http://www.havocscope.com/products.htm. (дата звернення: 10.12.2019)

${ }^{7}$ Paulus I., Simpson C. Opportunity, Benefit, and Subjective Disposition: Determinants of Nonprofessional Smuggling. The Pacific Sociological Review. Vol. 24. № 3 (Jul., 1981). P. 299-327.

${ }^{8}$ Брейтуэйт Д. Преступление, стыд и воссоединение / Пер. с англ. Н.Д. Хариковой; под общ. ред. М.Г. Флямера. М. : МОО Центр “Судебно-правовая реформа”. 2002. С. 210.

${ }^{9}$ Визначення митної вартості та підтвердження країни походження: Офіційний портал Державної фіскальної служби України URL: http://poltava.sfs.gov.ua. (дата звернення: 10.12.2019) 
2. Costs related to payment of customs duties and taxes.

3. Costs related to distribution (sale), since in most cases illegally imported goods are in the shadow segment of the market or legalized contrary to established requirements.

4. Regulation of intellectual property rights (audio and video recordings, finished products for domestic or industrial use, etc.).

In the economic sense, offenses related to the movement of goods / items across the customs border have traditionally been associated with tax evasion, fees, customs duties, etc., giving some reason to consider such offenses to be tax offenses.

However, it should be emphasized that these offenses are heterogeneous. They may be related to the trafficking of both illicit goods / items and illicit ones (such as drug smuggling). Obviously, the second type of offense is unrelated to tax evasion, since it is impossible to tax transactions with prohibited items.

However, if the nature of the offenses related to the movement of goods / items across the customs border is purely economic, then their legal nature is much more complicated.

Smuggling in Ukraine is an exclusively criminal act. Along with it in MK Ukraine there is a kind of offense called "violation of customs rules". Violation of customs rules is unlawful, guilty (intentional or negligent) acts or omissions that encroach on the procedure of moving goods, vehicles for commercial purposes across the customs border of Ukraine, established by the MK of Ukraine and presenting them to the customs authorities for carrying out customs control and customs clearance, as well as transactions with goods under customs control or control which are assigned to the customs authorities by this Code or other laws of Ukraine, and for which this Code provides for administrative liability (Article 458 of the Customs Code of Ukraine) ${ }^{10}$. Administrative liability for offenses arises if these offenses do not entail criminal liability.

Thus, the difference in the degree of public danger between criminal and customs offenses is due to the characteristics of the objects of the respective actions. And in a simplified form, smuggling can be presented as a "criminal offense". In this case, smuggling in Ukraine mainly involves items seized or restricted in civilian circulation. A certain exception is the subject of the criminal offense under Article 201-1 of the Criminal Code of Ukraine ${ }^{11}$.

\footnotetext{
10 Митний Кодекс України: Закон України від 13.03.2012 № 4495-VI. URL: https://zakon.rada.gov.ua/laws/show/4495-17/ed20120603(дата звернення: 10.12.2019)

11 Кримінальний кодекс України: Закон України від 17.01.2002 № 4495-VI. URL: https://zakon.rada.gov.ua/laws/show/2341-14. (дата звернення: 10.12.2019)
} 
Therefore, as a whole, smuggling, as opposed to violation of customs rules, cannot be considered as a kind of tax evasion or other payments today.

However, the question arises: does the economic nature of the smuggling persist with the position of the legislator? It seems that, because modern smuggling, like other types of offenses related to the movement of goods / items across the customs border, as will be shown below, is a kind of shady business done by organized groups. And such activity is purely economic, business, and this is a feature of organized crime.

In view of the above, it should be concluded that the offenses related to the movement of goods / items across the customs border are considered in two aspects:

1) economic, where such offenses are specific types of illegal activity and are part of a shadow economy, which involves a purely criminal business (when it comes to the movement of objects that are restricted or prohibited in civil circulation) and illegal economic activity (illegal transactions with authorized goods). At the same time such offenses can be considered as tax violations, since the main purpose of the figure is to receive income in a minimal time by minimizing taxes and other obligatory payments;

2) legal, where violation of customs rules is a generic concept for a customs offense with a similar name and criminal offenses (regardless of which section of the Special Part of the Criminal Code is a specific act).

However, these approaches, when considered separately, do not allow us to form a comprehensive vision: in the economic context, the antisocial nature of such activity is ranked second; in the legal context, it is necessary to emphasize the subjective assessment of the degree of public danger of certain actions and, accordingly, the classification of offenses of different sectoral affiliation. Thus, until 2011, the Criminal Code of Ukraine contained criminal liability for the so-called "commodity smuggling". Decriminalization of the latter led to its normative "transformation" into "violation of customs rules".

For the purposes of this study, it is advisable to rely on the European Court of Human Rights approach (ECtHR) to determining the sectoral affiliation of an action for the purpose of applying the Convention on Human Rights when developing an approach to understanding offenses related to the movement of goods / items across the customs border and fundamental freedoms.

In its practice, the ECtHR has widely used an autonomous interpretation, which is that the ECtHR does not consider binding on itself the meaning which a term has within the legal system of a State party to the Convention. In doing so, the ECtHR constantly emphasizes the need to take into account the specificity, uniqueness of a particular situation in different states, if the issue of whether a certain right or a violation has been resolved, that is, the Convention necessarily interprets the view of the current conditions in the present state at the time consideration of a specific case. 
Thus, the ECtHR uses the so-called "Engel criteria": is the offense a criminal offense under national law; what character it is; what purpose is punished for it and how severe it is ${ }^{12}$.

Another aspect is the correlation between smuggling and other criminal offenses related to the movement of certain objects across the border (for example, Articles 199, 200, 203-1 of the Criminal Code). Please note that they are an internally heterogeneous group: these acts are criminal offenses, but if you say that the systemic features of smuggling are the place of crime (customs border) and the method (outside customs control or with concealment from customs control), then directly these signs in Art. 199, 200, 203-1 of the Criminal Code are not specified. However, according to the logic of committing such acts, their subjects cross the border in various ways, among which are the evasion of customs control or concealment from customs control. These acts are criminal offenses in the field of economic activity, which means that they not only encroach on the same object, but also that they are manifestations of shadow economic activity. However, if the carriage, transfer for the purpose of sale of counterfeit transfer documents, payment cards or their use or sale (Art. export-import disks for laser reading systems, dies, equipment and raw materials for their production, since such actions are illegal because, as an indirect purpose, there is an evasion of mandatory payments.

Therefore, one can speak of legal grounds for dealing with smuggling, other criminal offenses related to the illegal movement of goods / items across borders, and breaches of customs rules in a single criminological context. Their totality defines the concept of "offenses related to the movement of goods / items across the customs border". The economic aspect determines the nature of the actions related to the movement of any goods / items across the customs border.

In the modern world, the border is losing its isolation value and acquiring a number of new features, including economic. This clearly shows itself in cross-border cooperation. The main task of the latter is to establish effective economic interaction, to create a favorable foreign economic investment climate. Border territories are peripheral, their economic development opportunities are determined by their proximity to the state border, so they are somewhat limited. The development of human capital, the preservation of cultural heritage and ecological diversity are all components of the economic potential of the territories on both sides of the border ${ }^{13}$.

12 Справедливое судебное разбирательство в международном праве: юридический сборник / Бюро ОБСЕ по демократическим институтам и правам человека. Варшава, 2016. C. 79.

${ }^{13}$ Орловська Н. Кримінальні загрози безпеці транскордонного співробітництва. Вісник Начіональної академії Державної прикордонної служби Украӥни: Юридичні науки. 2018. Вип. 2. URL: file:///C:/Users/ASUS/Downloads/vnadpcurn_2018_2_3.pdf. (дата звернення: 11.12.2019). 
In this context, the nature of the threats is also thought to be predominantly economic. In this regard, offenses related to the movement of goods / items across the customs border have all the characteristics of a business: voluntary initiative nature of the activity, organization, availability of a plan for carrying out this activity, systematic profit, partnerships, a certain place in the shadow economy of both the region and the country as a whole. And the fact that this business is illegal does not change its economic nature.

The economic dimension of offenses related to the movement of goods / items across the customs border should be individualized depending on the individual's desire to satisfy his or her needs. Individuals who use illegally imported goods meet their needs to obtain the desired goods, while individuals who supply such goods seek to meet their income needs. Thus, for a certain part of the population living in the border areas, committing these offenses has become the nature of established "fishing". However, in any case, it is about meeting economic needs. Actually, the consumer value of the offense becomes only at the end of the "commodity chain", when the specific product gets to an individual.

The criminological component involves the analysis of the criminal situation: indicators and tendencies of socially dangerous behavior, peculiarities of types and forms of organized criminal activity in the relevant sphere, etc.

The economic-criminological dimension of the study of offenses related to the movement of goods / items across the customs border includes their consideration in the context of the shadow economy.

The shadow economy should be understood as an economic activity related to the misappropriation of a part or value of a property or a part of property by a person or a group of persons due to various kinds of distortion of objective information about cash flows and tangible assets, distortion of primary accounting data to confuse sources of income., as well as through lobbying through implementation of relevant legislation. In other words, it is the production, distribution, exchange and consumption of inventory that is uncontrolled by societies ${ }^{14}$.

In its form, the shadow economy is an illegal business that includes both illegal foreign economic transactions, in particular, and offenses related to the movement of goods / items across the customs border.

Therefore, offenses related to the movement of goods / items across the customs border are a shady business that also contains signs of criminal business. Like other types of shadow business, these socially dangerous acts play an ambiguous role in the economic system of any state: on the one hand,

${ }^{14}$ Сирбу К.Г., Куцемір І.В. Тіньова економіка: причини, види, наслідки. Економіка України. 2017. № 1. С. 56-63. 
they have a significant impact on the commodity mass, leading to demand disparities - supply shortfalls in the state budget of taxes and customs payments; on the other, it cannot be denied that they provide employment (main or secondary) in the border regions and the availability of goods at the market at a more favorable price for the consumer ${ }^{15}$.

This type of shady business is more profitable than legal activity because the benefits of tax evasion and tax evasion far outweigh the risk of being held accountable, which, frankly, is not a threatening factor for offenders today.

Thus, from all the above arguments, one can conclude that the purely economic nature of all offenses related to the movement of goods / items across the customs border. Such movement occurs, as a rule, for business purposes and not for personal consumption, across the customs border, subject to the violation of the established customs rules and procedures, and regardless of the value of the goods / items being moved.

\section{Offenses related to the movement of goods / items across the customs border as a cross-border business}

Considering the relativity of legislative assessments on the degree of public danger of shadow business, it seems appropriate to address organized crime as a form of shadow business in the area of moving goods / items across the customs border.

According to V.V. Lunyev, the understanding of organized crime is even less clear today than violent, self-serving or economic ${ }^{16}$. However, the opinion of Y.I. Gilinsky is correct that it is important not so much a formal definition of organized crime as an understanding of its nature, essence ${ }^{17}$.

Experts emphasize the existence of two main approaches to the definition of organized crime: the first relates to organized crime those crimes committed by groups with certain organizational characteristics that are judged by the judiciary; the second is that the relevant normative acts list the crimes the perpetrators of which are guilty of organized crime, although it is criticized by many criminologists. Types of organized crime are constantly changing, so it is impossible to predict a comprehensive list of them ${ }^{18}$.

\footnotetext{
15 Орловська Н. А. Зарубіжний досвід запобігання контрабанді(на прикладі Китаю). Актуальні проблеми кримінального права, процесу, криміналістики та оперативнорозшукової діяльності: тези II Всеукраїнської науково-практичної конференції (Хмельницький, 2 березня 2018 року). - Хмельницький : Вид-во НАДПСУ, 2018. С. 78-82.

16 Лунеев В. В. Преступность ХX века: мировые, региональные и российские тенденции / В. В. Лунеев. [изд. 2-е, перераб. и доп.]. М. : Волтерс Клувер, 2005. С. 35.

${ }^{17}$ Гилинский Я. И. Криминология. Курс лекций. СПб., 2002. С. 207.

18 Закалюк А. П. Організована злочинна діяльність:сутність та потреби нормативного визначення. Новий Кримінальний кодекс України: Питання застосування і вивчення: Матер. міжнар. наук.-практ. конф., м. Харків, 25-26 жовтня 2001р. К.; Х., 2002. С. 62.
} 
When it comes to organized crime in the context of an activity approach, the following features of organized crime are emphasized in the professional literature:

- fatigue, regularity and duration;

- careful planning of criminal activity;

- division of labor, differentiation into managers and subordinates (specialists of different level and specialization);

- creation of cash insurance stocks ("commons") used for the needs of a criminal organization.

But it remains unclear as to how correct it is that the concept of "organized crime" covers both the perpetrators and their activities. At the same time, the final ambiguity of the concept complicates the real estimation of the prevalence of the phenomenon, allows to take into account how the simplest forms of complicity are organized, leads to the leveling of the efforts of law enforcement agencies ${ }^{19}$.

It seems that the concept of organized crime as the most socially dangerous type of organized activity is subject to analysis as a combination of forms (certain structures) and types (certain offenses).

All types of organized criminal activity are economic in nature. Organized crime as a regulator of the shadow market performs a number of economic functions: meeting the needs of goods that were missing or lacking in the market, coordinating the activities of the entities of illegal economic activity, monitoring the implementation of agreements and out-of-process conflict resolution, job creation and attracting qualified specialists for the control structures, their protection, elimination of bureaucratic obstacles, financing and crediting, etc.

For domestic organized crime, active penetration into the sphere of economic activity is characteristic.

Organized crime in Ukraine has a dual nature - one of its components arose from the involvement of criminal organizations in the shadow and legal economies, and the second component originated directly in the legal economy - through the commission of economic offenses by legalized business entities. Many business entities are involved in illegal business activities and are directly interested in the functioning of criminal organizations, which is where the smugglers begin to cover, to increase their assets, strengthen their position in the market, eliminate competitors, reduce transaction costs, and so on.

19 Шостко О. В. Визначення поняття “організована злочинність” у зарубіжній кримінології. Вістник академії правових наук Украӥни. 2014/ № 1. С. 180-189. 
The peculiarity of domestic organized crime is that the shadow economy is the basis for its active expansion, not criminal activity.

When analyzing organized forms of offenses related to the movement of goods / items across the customs border, a systemic effect becomes apparent: the illegal movement of goods / items across the customs border of Ukraine enhances the criminal direction of economic development, which is manifested in the activation of organized criminal activities in the economy, exacerbated socio-economic situation in society, deterioration of the quality of life of the population and the emergence of disparities in spatial and regional development.

Thus, the organized forms of these offenses influence the strengthening of the criminal aspect of economic development, which results in widespread self-reproduction of socially dangerous behavior.

Shadow business is a manifestation of a systemic problem. Formally, there may be no organized criminal structure of which individual offenders are members. However, they represent residents of the territories who, by establishing corrupt links with law enforcement officers, are engaged in highly specialized shadow activity, having persistent self-motivation, incomeseeking intent, hiding activities from social control by establishing corruption ties. In view of this, the mechanisms and tactics of illegal activity are constantly being adjusted in accordance with the change of the rules of registration of import to the territory of Ukraine and export of goods from it, new measures are being developed to counteract the law enforcement agencies.

Thus, offenses related to the movement of goods / items across the customs border represent organized shadow activity (shadow business), the subjects of which can be both separate structures (eg organized criminal groups) and amorphous factions that formed in the border areas as a manifestation of the established form of employment of the local population.

Another aspect of the analysis of offenses related to the movement of goods / items across the customs border is the issue of their transnationality / cross-border.

Traditionally, it is noted that transnational character, inherent within the territory of one state, is inherent in these actions, unless free economic zones are introduced (i.e. no customs border is imposed), these offenses simply cannot be committed. The offenses related to the movement of goods / items across the customs border are committed by organized groups operating in several states.

The concept of transnationality was defined at the convention level in the UN Convention against Transnational Organized Crime (2000). Article 3 of this Convention is transnational in nature if it is committed: more than one 
State; in one State, but a substantial part of its planning, management or control preparation takes place in another State; in one state, but with the participation of an organized criminal group committing criminal activity in more than one state; in one state, but its significant consequences are manifested in another state ${ }^{20}$.

It follows that "transnationality" involves the question of criminalization of a particular act in several states, the preparation / commission / occurrence of the consequences of such a crime in more than one country, as well as the countries of origin and activity of the offenders. All this determines the jurisdiction of the "interested" states in bringing those responsible to justice. It is, in fact, the creation of a common criminal space. Otherwise, there will be no legal basis for recognizing certain acts as crimes and, as a consequence, for preventing these acts.

Thus, the issue of transnationality is, in fact, a problem of the place where the committed or completed crime is committed, with the obligation of multilateral criminalization and the penalization of appropriate actions.

Transnationality of a crime means going beyond the national criminal jurisdiction, which is generally delineated on state borders (because there are some cases of extending jurisdiction of the state to acts committed outside its borders). Against this background, the concept of transnational crime distinguishes the concept of transborder crime.

Thus, transnationality is a manifestation of the globalization of criminal activity, its worldwide distribution by specialization (activities). In particular, it is emphasized in the literature that the expansion of the scale of smuggling is based on economic interests as a result of globalization, which has replaced the confrontation between the two world systems. However, in this aspect, attention is drawn not to the nature of smuggling, which, as noted, is a crossborder crime, but to the factors behind the increase in the scope of smuggling activities. Globalization seems to affect the deterioration of the criminal situation not only at the supranational but also at the national level.

In turn, cross-border, in contrast, reflects the process of globalization mediating regional features of socially dangerous activities. Glocalization can be described as a domestic crime in general, as well as some of its structural elements that have a specific territorial link. This is most clearly manifested in cross-border crime

Thus, cross-border crime mediates transnational crime in crimes that reflect the socio-economic, political, demographic specificities of the territories on both sides of the border. It embodies local criminal features, with locality signifying regional rather than national level.

\footnotetext{
${ }^{20}$ Конвенція ООН проти транснаціональної організованої злочинності: Міжнародний документ від 15.11.2000. URL: http://zakon3.rada.gov.ua/ (дата звернення: 12.12.2019)
} 
On the basis of the above, it should be concluded that the offenses related to the movement of goods / items across the customs border, in their criminalized part, are transboundary crimes. For example, as regards smuggling in general and drug smuggling, in particular, as a cross-border issue, it is listed in the 2016-2020 Cross-Border Cooperation Program, one of the objectives of which is to prevent smuggling ${ }^{21}$.

If we talk about the totality of these offenses, they act as a cross-border shadow business, which in criminological terms leads to the involvement of broad sections of the population of the border territories in criminal activity through the formation of stable anti-social ties between citizens of different countries, the formation of corrupt representatives of schemes of corruption. authorities of neighboring states, etc. But it should be emphasized that crossborder crime has not yet become a factor of economic growth in any country. Cross-border organized crime is a kind of transnational organized crime.

Considering the systemic links of offenses related to the movement of goods / items across the customs border as a kind of shadow business, one should distinguish money laundering. Between them there is feedback (twoway). On the one hand, these offenses are a source and sector of the shadow economy, a prerequisite for the emergence of money laundering as a phenomenon, on the other, - laundering is a necessary component in the scheme of modern shadow business.

It should be noted that to characterize the relationship of offenses related to the movement of goods / items across the customs border, with the laundering of income in the literature, different terms are used: stage, stage, method, means, source, mechanism, process. For example, it is noted that "smuggling can serve as a source of criminal proceeds and a means of legalizing them"22. It is believed that the initial stage of money laundering involves the physical transportation of money (cash) abroad. The integration or return and legalization of money laundering is the final stage of this crime. T.A Dikanova, V.E. Osipov believes that "currency smuggling is usually the first stage in money laundering",23.

Offenses related to the movement of goods / items across the customs border are predicate for the laundering of proceeds of crime. In this connection, it is advisable to mention the statement: "considering the specific

${ }^{21}$ Про затвердження Державної програми розвитку транскордонного співробітництва на 2016-2020 роки: Постанова Кабінету Міністрів України від 23.08.2016 р. № 554. URL: http://zakon3.rada.gov.ua/ (дата звернення: 12.12.2019)

22 Контрабанда на “кордоні": інформація 3 Офіційного сайту Служби безпеки України // URL: https://ssu.gov.ua/ (дата звернення: 12.12.2019)

${ }^{23}$ Диканова Т. А., Осипов В. Е. Борьба с таможенными преступлениями и отмыванием “грязных" денег: Методическое пособие,- М.: ЮНИДАНА, Закон и право, 2000. 310 с. 
relationship of predicate crimes (major, secondary) with legalization, we can talk about the presence and functioning of direct (unilateral) and inverse (bilateral) relations between them" 24 .

Therefore, in case of illegal transfer (export) of capital committing such offenses acts as a way and stage of money laundering. However, part of the funds is illegally returned to Ukraine. This can be explained by the fact that in most foreign countries organized crime is concentrated mainly in the sphere of criminal business, and in Ukraine it operates in all the most profitable areas.

The problem of money laundering has become urgent in Ukraine precisely with the emergence and development of organized criminal activity, one of the manifestations of which is the offenses related to the movement of goods / objects across the customs border. Money laundering is the technological side of the existence of modern organized crime

Thus, from all of the above, it can be concluded that the offenses related to the movement of goods / items across the customs border and money laundering are closely interrelated, and there is a (two-way) relationship between them.

\section{CONCLUSIONS}

Thus, within the framework of the conducted research it is possible to reach the following conclusions.

Considering the unity of content and mechanism of socially dangerous activities related to the movement of goods / items across the customs border outside the customs control or to conceal from customs control under the generic concept of "offenses related to the movement of goods / items across the customs border" to combine smuggling, other criminal offenses related to the movement of goods / items across borders, violation of customs rules.

It can also be concluded that the offenses related to the movement of goods / items across the customs border are a shady business that also contains signs of criminal business. Like other types of shadow business, these socially dangerous acts play an ambiguous role in the economic system of any state: on the one hand, they have a significant impact on the commodity mass, leading to demand disparities - supply shortfalls in the state budget of taxes and customs payments; on the other, there is no denying that they provide employment (main or secondary) in the border regions and the availability of goods on the market at a more favorable price for the

24 Журавель В.В. Предикатний фактор у структурі елементів криміналістичної характеристики легалізації (відмивання) доходів, одержаних злочинним шляхом. Вісник правових наук. 2015 р. № 1(40). С. 128-136. 
consumer. And in such circumstances, the economic and criminological nature of these offenses is manifested.

These offenses are a highly profitable type of illegal business activity, the profit margin of which compensates economic agents material costs and moral damages from the risks of its implementation. Such a vision provides an opportunity to look at these offenses as a criminologically unified set of activities that intersects with transnational / cross-border economic organized crime.

It is important that the economic and criminological dimension of offenses related to the movement of goods / items across the customs border, in view of the activity approach in understanding socially dangerous behavior, makes it necessary to consider the problems of organized forms of shadow business: on the one hand, business cannot be disorganized; the organized nature of economic activity inherent in entrepreneurship; on the other hand, the criminological literature and regulatory acts present an approach to organized crime as a phenomenon, while at the same time the issues of organized forms of noncriminalized socially dangerous activity remain insufficiently explored.

\section{SUMMARY}

The article deals with a comprehensive study of the legal nature of offenses related to the movement of goods / items across the customs border, their current state and conceptual directions of prevention of this offense.

The idea of identifying offenses related to the movement of goods / objects across the customs border as a criminological group of offenses, including crimes and administrative offenses, which are mainly a cross-border shadow business. It has been found that the fact of committing offenses related to the movement of goods / items across the customs border has the character of business activities carried out by organized entities that are subjects of the shadow economy. The modern conceptual model of organized crime in the part of the analysis of amorphous structures as a modern type of criminal groups has been improved.

An in-depth understanding of the systemic links between the shadow business, organized crime and corruption in the area of offenses related to the movement of goods / items across the customs border as a type of crossborder shadow business.

\section{REFERENCES}

1. Bhagwati J., Hansen B. A Theoretical Analysis of Smuggling. The Quarterly Journal of Economics. Vol.87. № 2. (May, 1973). P. 172-187.

2. Sheikh M.A. Smuggling, production and welfare. Journal of International Economics. 1974. № 4. P. 355-364. 
3. Pitt M. Smuggling and price disparity. Journal of International Economics. 1981. № 11. P. 447-458.

4. Norton D.A. On the Economic Theory of Smuggling. Economica, New Series. Vol. 55. - № 217. (Feb., 1988). P. 107-118.

5. Chowdhury F.L. Smuggling, Tax Structure and The Need for AntiSmuggling Drive. Fiscal Frontier. Vol. VI. 2000. URL: http://www.answers.com/topic/faizul-latif-chowdhury.

6. Black Market Contraband Index. URL: http://www.havocscope.com/ products.htm.

7. Paulus I., Simpson C. Opportunity, Benefit, and Subjective Disposition: Determinants of Nonprofessional Smuggling. The Pacific Sociological Review. Vol. 24. № 3 (Jul., 1981). P. 299-327.

8. Брейтуэйт Д. Преступление, стыд и воссоединение / Пер. с англ. Н.Д. Хариковой; под общ. ред. М.Г. Флямера. М. : МОО Центр “Судебно-правовая реформа". 2002.

9. Визначення митної вартості та підтвердження країни походження: Офіційний портал Державної фіскальної служби України URL: http://poltava.sfs.gov.ua. (дата звернення: 10.12.2019)

10. Митний Кодекс України: Закон України від 13.03.2012 № 4495-VI. URL: https://zakon.rada.gov.ua/laws/show/4495-17/ed20120603

11. Кримінальний кодекс України: Закон України від 17.01.2002 № 4495-VI. URL: https://zakon.rada.gov.ua/laws/show/2341-14. (дата звернення: 10.12.2019)

12. Справедливое судебное разбирательство в международном праве: юридический сборник / Бюро ОБСЕ по демократическим институтам и правам человека. Варшава, 2016. С. 79.

13. Орловська Н. Кримінальні загрози безпеці транскордонного співробітництва. Вісник Національної академії Держсавної прикордонної служби України: Юридичні науки. 2018. Вип. 2. URL: file://C:/Users/ ASUS/Downloads/vnadpcurn_2018_2_3.pdf.

14.Сирбу К.Г., Куцемір І.В. Тіньова економіка: причини, види, наслідки. Економіка України. 2017. № 1. С. 56-63.

15. Орловська Н. А. Зарубіжний досвід запобігання контрабанді(на прикладі Китаю). Актуальні проблеми кримінального права, процесу, криміналістики та оперативно-розшукової діяльності : тези II Всеукраїнської науково-практичної конференції (Хмельницький, 2 березня 2018 року). Хмельницький: Вид-во НАДПСУ, 2018. С. 78-82.

16. Лунеев В. В. Преступность XX века : мировые, региональные и российские тенденции. изд. 2-е, перераб. и доп.. М. : Волтерс Клувер, $2005.35 \mathrm{c}$.

17. Гилинский Я. И. Криминология. Курс лекций. СПб., 2002. 
18. Закалюк А. П. Організована злочинна діяльність:сутність та потреби нормативного визначення. Новий Кримінальний кодекс України: Питання застосування і вивчення: Матер. міжнар. наук.-практ. конф., м. Харків, 25-26 жовтня 2001р. К.; Х., 2002.

19. Шостко О. В. Визначення поняття “організована злочинність” у зарубіжній кримінології. Вістник академії правових наук Украӥни. 2014. № 1. С. 180-189.

20. Конвенція ООН проти транснаціональної організованої злочинності: Міжнародний документ від 15.11.2000 / URL: http://zakon3.rada.gov.ua/

21. Про затвердження Державної програми розвитку транскордонного співробітництва на 2016-2020 роки: Постанова Кабінету Міністрів України від 23.08.2016 p. № 554. URL: http://zakon3.rada.gov.ua/

22. Контрабанда на “кордоні”: інформація з Офіційного сайту Служби безпеки України. URL: https://ssu.gov.ua/

23. Диканова Т. А., Осипов В. Е. Борьба с таможенными преступлениями и отмыванием “грязных" денег: Методическое пособие,- М.: ЮНИДАНА, Закон и право, 2000. 310 с.

24. Журавель В. В. Предикатний фактор у структурі елементів криміналістичної характеристики легалізації (відмивання) доходів, одержаних злочинним шляхом. Вісник правових наук. 2015 р. № 1(40). C. $128-136$.

Information about the authors: Palamarchuk G. V., Lecturer at the Department of Criminal Law, Process and Criminology, International Humanitarian University 33, Fontanska Road str., Odessa, 65009, Ukraine

Neledva N. V., Associate Professor at the Department of Criminal Law, Process and Criminology, International Humanitarian University 33, Fontanska Road str., Odessa, 65009, Ukraine 